Check for updates

The BMJ

Cite this as: BMJ 2021;372:n155 http://dx.doi.org/10.1136/bmj.n155 Published: 20 January 2021

\section{THE BIG PICTURE}

\section{Covid-19: Gothic sanctuary gives hope for the future}

\section{Alison Shepherd}

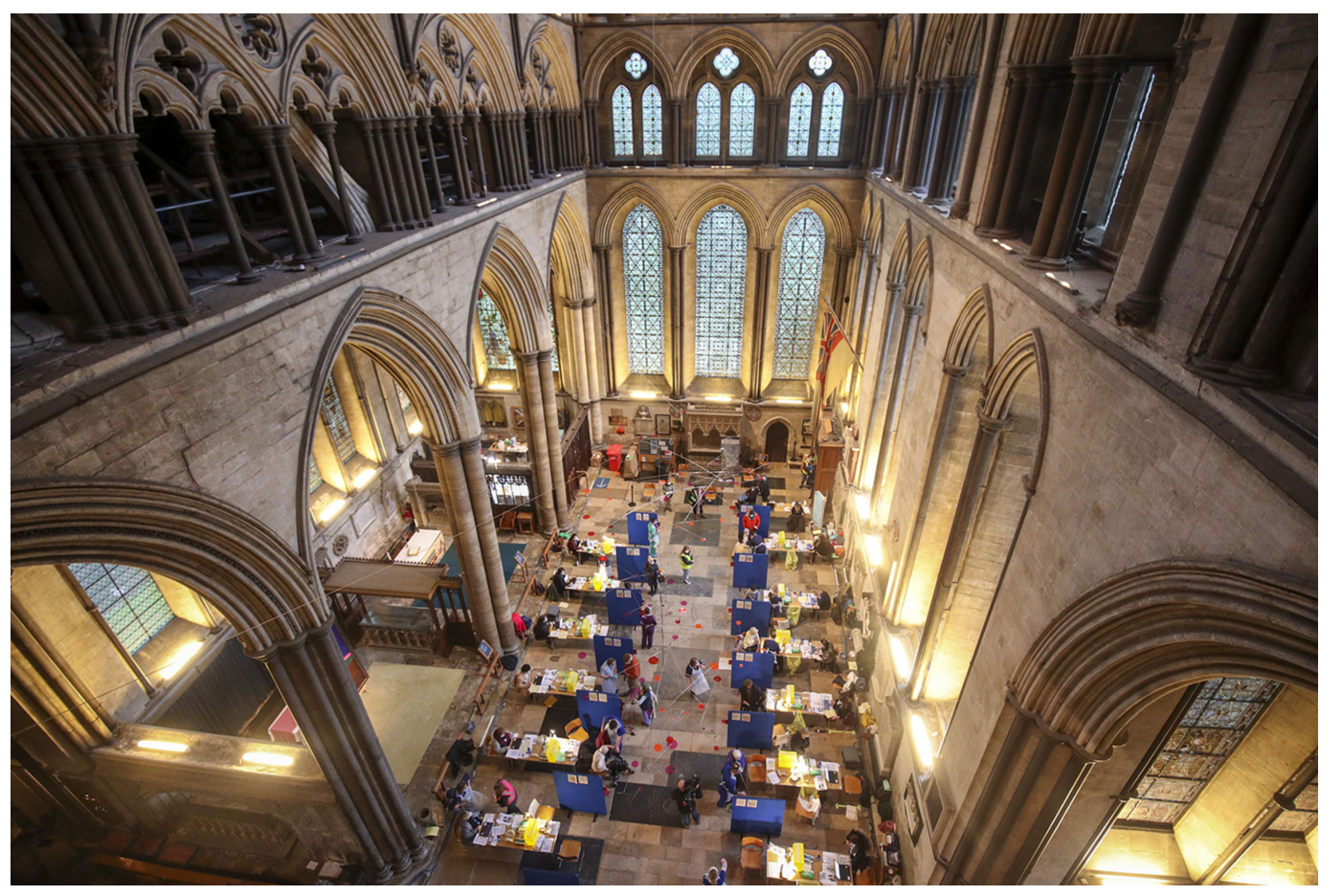

To the sound of organ music, hundreds of people aged over 80 receive their Pfizer-BioNTech covid-19 vaccination inside the grandeur of Salisbury Cathedral transept.

On Saturday 16 January the cathedral was turned into a pop-up vaccination hub by Sarum South Primary Care Network. Its co-clinical director Dan Henderson said around 1000 patients and staff were vaccinated in one day.

Nicholas Papadopulos, the dean of Salisbury, told the Guardian, "This place has stood here for 800 years to give glory to God, and to serve the city and the region. What better way could there be to do that than hosting Salisbury's stage in the vaccination programme. It is absolutely wonderful." ${ }^{1}$

Lichfield and Blackburn cathedrals have also opened their doors to help the vaccination drive, along with race courses, sports halls, and other venues closed because of the current lockdown.

From the start of this week, across the UK people aged 70 and over and the clinically extremely vulnerable also began to be invited to join the 3.8 million people who have so far received their first vaccine dose. The government has pledged to offer a vaccine to everyone over the age 70 , all health and social care workers, and clinically extremely vulnerable people by mid-February.

1 Morris S. Covid vaccine jabs accompanied by organ music at Salisbury Cathedral. Guardian. 16 Jan 2021. https://www.theguardian.com/world/2021/jan/16/covidjabs-to-be-accompanied-by-organ-music-at-salisbury-cathedral.

This article is made freely available for use in accordance with BMJ's website terms and conditions for the duration of the covid-19 pandemic or until otherwise determined by BMJ. You may use, download and print the article for any lawful, non-commercial purpose (including text and data mining) provided that all copyright notices and trade marks are retained. 